(n)

\title{
Prepuberal light phase feeding induces neuroendocrine alterations in adult rats
}

\author{
C García-Luna, P Soberanes-Chávez and P de Gortari
}

Department of Neurosciences Research, Molecular Neurophysiology Laboratory, National Institute of Psychiatry Ramón de la Fuente Muñiz, Mexico City, Mexico

Correspondence should be addressed to P de Gortari Email gortari@imp.edu.mx

\begin{abstract}
Feeding patterns are important factors in obesity evolvement. Time-restricted feeding schedules (tRF) during resting phase change energy homeostasis regulation, disrupting the circadian release of metabolism-regulating hormones, such as leptin, insulin and corticosterone and promoting body weight gain. Thyroid (HPT) and adrenal (HPA) axes exhibit a circadian regulation and are involved in energy expenditure, thus studying their parameters in tRF paradigms will elucidate their role in energy homeostasis impairments under such conditions. As tRF in young animals is poorly studied, we subjected prepuberal rats to a tRF either in light (LPF) or in darkness phase (DPF) and analyzed HPT and HPA response when they reach adulthood, as well as their arcuate $(A R C)$ and paraventricular (PVN) hypothalamic nuclei neurons' sensitivity to leptin in subsets of 10-week-old animals after fasting and with i.p. leptin treatment. LPF group showed high body weight and food intake, along with increased visceral fat pads, corticosterone, leptin and insulin serum levels, whereas circulating $T_{4}$ decreased. HPA axis hyperactivity was demonstrated by their high PVN Crf mRNA expression; the blunted activity of HPT axis, by the decreased hypophysiotropic PVN Trh mRNA expression. Trh impaired expression to the positive energy balance in LPF, accounted for their ARC leptin resistance, evinced by an increased Npy and Socs3 mRNA expression. We concluded that the hyperphagia of prepuberal LPF animals could account for the HPA axis hyperactivity and for the HPT blocked function due to the altered ARC leptin signaling and impaired NPY regulation on PVN TRH neurons.
\end{abstract}

\author{
Key Words \\ - proTRH \\ - proCRF \\ - leptin \\ - feeding schedules
}

\section{Introduction}

Obesity is a major worldwide health concern; its prevalence has doubled in the last 35 years in children and adults (Flegal et al. 2016, Ogden et al. 2016), it may result from an imbalance between energy intake and energy expenditure leading to increased body fat content. In humans, environmental factors, such as lifestyle and eating habits, have a direct influence on body weight. Changing eating schedules from the activity to the resting phase, increases the risk of individuals to develop metabolic alterations and weight gain, as seen in shift workers and in people who eat during the night (Qin et al. 2003, Al-Naimi et al. 2004, Antunes et al. 2010, Amani \& Gill 2013). Moreover, limiting food intake to an interval of 10-12h during activity phase, regardless of food quality or quantity, reduces body weight (Gill \& Panda 2015). Thus, uncoupling the release of rest/activity cycleinduced hormones with feeding schedules by changing eating habits, impairs individuals' energy homeostasis.

Published by Bioscientifica Ltd 
In fact, reports of time-restricted feeding paradigms (tRF) show the effects of feeding time on metabolism of rodents: energy homeostasis is impaired in animals eating regular chow during their resting phase (light phase), in comparison with that of animals fed during their activity phase (darkness phase) (Salgado-Delgado et al. 2010, Bray et al. 2013). In addition, when animals are fed with a high-fat diet (HFD) during the activity period, body weight gain diminishes and lipid and glucose metabolism improves in comparison with HFD-fed animals during the resting phase (Hatori et al. 2012, Tsai et al. 2013), showing that feeding time is relevant to maintain an adequate energy balance.

Expression and/or release of peripheral signals such as leptin (Ahima et al. 1998), insulin (La Fleur et al. 1999), glucagon (Ruiter et al. 2003), ghrelin (Bodosi et al. 2004), corticosterone (De Boer \& Van der Gugten 1987) and thyroid hormones (TH) (Jordan et al. 1980) have a circadian oscillation, either in response to light/darkness cycle or to feeding schedules. In particular, leptin serum content increases after a meal and when adipose tissue augments, inhibiting food intake and enhancing energy expenditure by activating the transcription of anorexigenic peptides (cocaine and amphetamine-regulated peptide (CART)/ proopiomelanocortin (POMC)) from the hypothalamic arcuate nucleus (ARC) and silencing that of orexigenic (neuropeptide Y (NPY/agouti-related peptide (AgRP)) ones (Cheung et al. 1997, Ahima et al. 1999, Elias et al. 1999). Orexigenic and anorexigenic neuron populations from the ARC project to thyrotropin-releasing hormone (TRH)and corticotrophin-releasing factor (CRF)-synthesizing neurons in the hypothalamic paraventricular nucleus (PVN) (Cone et al. 2001), modulating TRH and CRF expression and their neuroendocrine effects.

TRH and CRF direct hypothalamic-pituitary-thyroid (HPT) and adrenal (HPA) axes, respectively. Both axes are regulated by a negative feedback loop having $\mathrm{TH}$ and glucocorticoids (GC, corticosterone in rodents) as final effectors. TH influences energy balance activating the synthesis of uncoupling proteins in brown adipose tissue (BAT) and enhancing lipolysis (Lanni et al. 2003, Mullur et al. 2014). GCs stimulate the proliferation and differentiation of pre-adipocytes, promoting abdominal fat deposition (Bjorntorp 2001, Zilberfarb et al. 2001); in addition, they increase gluconeogenesis and glucose serum availability (Imai et al. 1990, Schmoll et al. 1996, Lin et al. 1998) and stimulate ARC NPY expression and food intake (Shimizu et al. 2008). TRH and CRF are allocated with anorexigenic actions revealed by their intracerebroventricular injections (Morley \&
Levine 1980, Rohner-Jeanrenaud et al. 1989, Kow \& Pfaff 1991). Leptin activates TRH and CRF expression; thus, conditions altering this hormone content, such as obesity or fasting, can affect energy expenditure and food intake through those peptides' actions (Fekete et al. 2006, Perello et al. 2010).

ARC NPY/AgRP neurons' projections into PVN and lateral hypothalamus are not completely mature after birth (Bouret et al. 2004, Baquero et al. 2014). Moreover, leptin exerts its anorexigenic effects on animals from the fourth week of age (Mistry et al. 1999), and its involvement in PVN TRH expression regulation requires ARC projection pathways (Legradi \& Lechan 1998), making the prepuberal stage critical for changes in animals' feeding that might prevail until adulthood. Although tRF studies have yielded a significant amount of data in adult rats, there is very little information about the response of neuroendocrine axes in younger animals under this feeding schedule.

We hypothesized that the programming of the neuroendocrine axes' function by hormones whose release depend on the rest/activity cycle may be impaired during early developmental stages by changing individuals' feeding habits to the resting phase of the day; and this impairment may be sustained up to adulthood provoking metabolic alterations. The aim of this study was to evaluate if tRF in prepubertal rats, whether in the light or darkness phase, could alter energy homeostasis and neuroendocrine axes regulation when those animals reach adulthood. In addition, we hypothesized an impaired leptin signaling as a candidate pathway involved in body weight gain of animals fed in the light phase.

\section{Methods}

\section{Animals}

All animal procedures were approved by Psychiatry Institute's Ethical Committee on Animal Experimentation and agreed with the Mexican official norm NOM-062ZOO-1999 for use and care of laboratory animals. Pregnant Wistar rats $(n=12)$ from the animal housing facility of the Psychiatry National Institute were housed individually under controlled light cycle (lights on from 0700 to $1900 \mathrm{~h}$ and temperature $\left(24 \pm 1^{\circ} \mathrm{C}\right)$ conditions, with ad libitum access to standard rat chow (Lab rodent diet \#5001, PMI feeds)) and water. The day of the delivery was identified as day 0 , and dams and pups were left undisturbed until weaning (postnatal day (PN) 21). At PN21, male pups (5-6 males per litter) were separated, individually caged

Published by Bioscientifica Ltd 
and divided into 3 experimental groups ( $n=22 /$ group): control group (C): animals were fed ad libitum with standard rat chow and had unrestricted access to water; light-phase fed (LPF) group: which had food available from 1700 to 0900 with ad libitum access to water; darknessphase fed (DPF) group that had food available from 2300 to 0700 with free access to water (Fig. 1A). The tRF schedule was performed from PN21 to PN35 (prepuberal stage) and after PN35 animals were left undisturbed with ad libitum access to rat chow and water until they reached adulthood (PN70). Body weight and food intake were measured weekly until PN70, when animals were killed by decapitation. Brains were excised, frozen on dry ice and kept at $-70^{\circ} \mathrm{C}$ until in situ hybridization (ISH) analyses of proTrh and proCrh mRNA expression were performed; adipose tissue subcompartments (white adipose tissue (WAT): mesenteric, subcutaneous, epididymal, perirenal retroperitoneal; brown adipose tissue (BAT): subscapular), and adrenal glands were dissected and weighted; trunk blood was collected for serum hormones' determination (triiodothyronine $\left(\mathrm{T}_{3}\right)$, thyroxine $\left(\mathrm{T}_{4}\right)$, insulin, leptin and corticosterone).

To evaluate hypothalamic neurons' response to fasting and to leptin administration, a subset of ten- week-old animals from the three experimental groups ( $n=4-6 /$ group) was subjected to a 48-h fasting and intraperitoneally (i.p.) administered with either vehicle (veh: $0.9 \%$ saline solution) or $0.1 \mu$ g per gram of body weight of recombinant mouse leptin (Calbiochem, Merck Millipore) twice a day (07:00 and 19:00h) during the 48-h fasting period, as previously reported (Bojanowska $\&$ Nowak 2007). After leptin administration, animals were refed, and food intake was recorded $6 \mathrm{~h}$ after food was made available. Body weight loss was measured by weighing animals before and after fasting and the percentage of the changes in body weight loss (\% delta $(\Delta))$ was calculated by taking the initial weight (10-weekold weight) as $100 \%$. At the end of the refeeding period, animals were killed by decapitation; adipose tissue subcompartments and adrenal glands were treated as mentioned before; brains were excised and maintained at $-70^{\circ} \mathrm{C}$ until real-time PCR (RT-PCR) analyses of ARC and PVN transcripts were performed.

\section{Determination of serum hormones' content}

Total serum $T_{3}, T_{4}$ and insulin were determined by commercial ELISA kits following manufacturer's
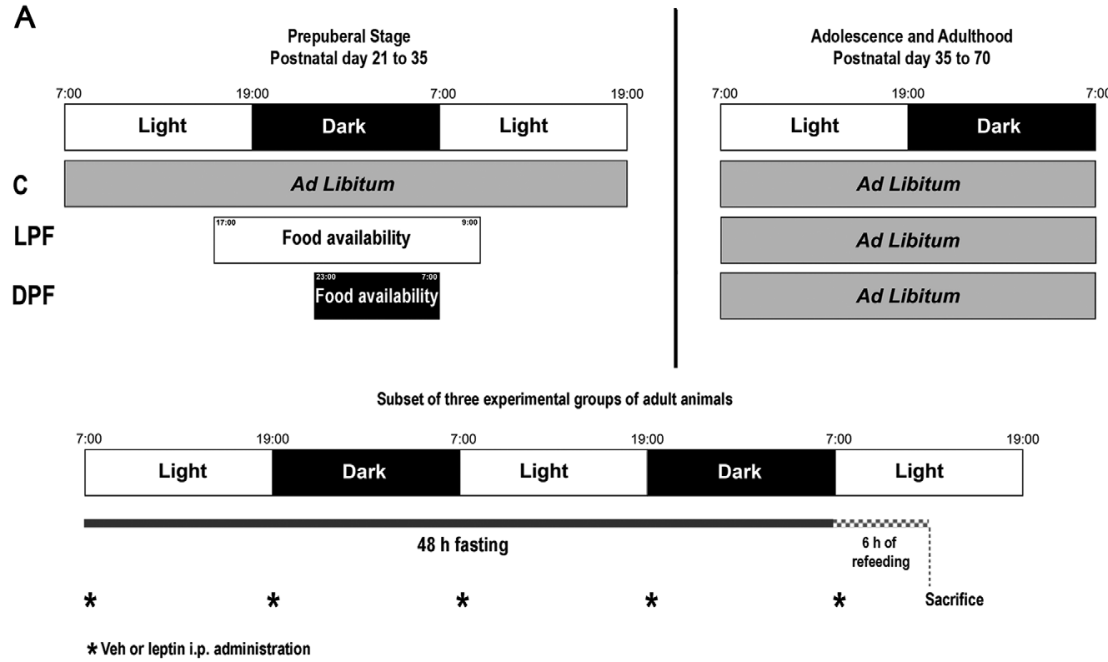

B
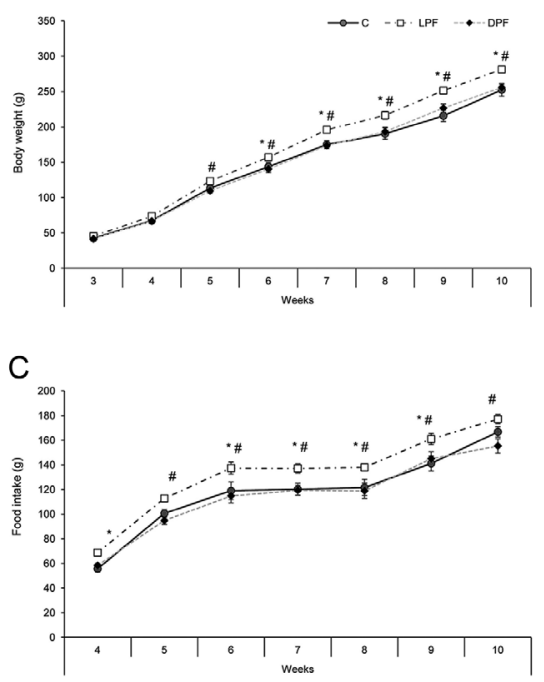

Figure 1

Experimental design, body weight and food intake. (A) Feeding schedule from postnatal day (PN) 21 to 35 of male rats. Control (C) group had ad libitum access to food and water, light-phase feeding (LPF) group had access to food from 17:00 to 09:00 h and free access to water and darknessphase feeding (DPF) animals had food availability from 2300 to $0700 \mathrm{~h}$ and free access to water. From PN 35 to 70 , all groups had ad libitum access to food and water after which animals were killed. A subset of three adult experimental groups were fasted for $48 \mathrm{~h}$ and i.p. administered every $12 \mathrm{~h}$ with vehicle (veh) or recombinant mouse leptin $(0.1 \mathrm{\mu g} / \mathrm{g}$ B.W.), once $48 \mathrm{~h}$ elapsed, animals were allowed to eat for $6 \mathrm{~h}$ and killed. (B) Weekly measurements of body weight of C, LPF and DPF animals. (C) Food intake data are the weekly average of the daily food consumption from week 4 to 10 of C, LPF and DPF animals. Data are expressed as the mean \pm S.E.M. in grams ( $n=22 /$ group). One-way ANOVA of repeated measures followed by Tukey's post hoc test showed differences between groups, ${ }^{*} P<0.05$ vs $C$; ${ }^{\# P}<0.05$ vs DPF. 
instructions (ALPCO, Salem, NH, USA); sensitivity: $\mathrm{T}_{3}, 0.2 \mathrm{ng} / \mathrm{mL}, \mathrm{T}_{4}, 0.5 \mu \mathrm{g} / \mathrm{dL}$ and insulin, $0.124 \mathrm{ng} / \mathrm{mL}$; inter-assay variability: $\mathrm{T}_{3}, 10.3 \%, \mathrm{~T}_{4}, 4.5 \%$ and insulin, 9.95\%; intra-assay variability: $\mathrm{T}_{3}, 9.6 \%, \mathrm{~T}_{4}, 4.3 \%$ and insulin, $5.79 \%$. Corticosterone and leptin serum concentrations were determined using Enzo Life Sciences ELISA kits (Farmingdale, NY, USA); sensitivity: corticosterone, $27 \mathrm{pg} / \mathrm{mL}$ and leptin, $67.2 \mathrm{pg} / \mathrm{mL}$; interassay variability: corticosterone, $13.1 \%$ and leptin, $11 \%$; intra-assay variability: corticosterone, $8.4 \%$ and leptin, $8.1 \%$.

\section{In situ hybridization hystochemistry analysis (ISH)}

Dissected brains were sectioned using a cryostat (Microm HM 525; Carl Zeiss IMT Corporation) at $-20^{\circ} \mathrm{C}$ to obtain $14 \mu \mathrm{m}$ thick coronal slices including the whole length of the PVN (aPVN: -0.84 to $-1.44 \mathrm{~mm}$ from bregma, mPVN: -1.44 to $-1.92 \mathrm{~mm}$ from bregma and cPVN: -1.92 to -2.28 from bregma) (Paxinos \& Watson 2005). For each PVN subcompartment, three sections per slide per animal were collected and adhered to Superfrost/Plus slides (Fisher Scientific). Sections were fixed with $4 \%$ paraformaldehyde at $4^{\circ} \mathrm{C}$ for $20 \mathrm{~min}$ in PBS buffer, digested with pronase $\left(24 \mathrm{U} / \mathrm{mL}\right.$; Calbiochem (Merck Millipore)) at $20^{\circ} \mathrm{C}$ for $2 \mathrm{~min}$, and air-dried before hybridization. A mixture of oligonucleotide probes complementary to the following base sequences of proTrh mRNA (GenBank accession number: NM_013046.2): 85-129, 407-471 and 568-612 and proCrf mRNA (GenBank accession number: NM_031019.1): 114-158, 284-328 and 536-580 were labeled by 3 '-tailing with $\left.{ }^{35} \mathrm{~S}\right]$ dATP $(1250 \mathrm{Ci} /$ mmol; PerkinElmer) using terminal deoxynucleotidyl transferase (Roche Diagnostics $\mathrm{GmbH}$ ). All oligonucleotide probes were synthesized by the Biotechnology Institute of the UNAM (Cuernavaca, Morelos, Mexico) and were BLAST-tested to evaluate probe's specificity, which was confirmed using rat database. We used non-complementary probes as negative controls, directed against the same proTrh mRNA nucleotide sequences as complementary probes (Arechiga-Ceballos et al. 2014, Alvarez-Salas et al. 2016). Hybridization protocol with oligonucleotide probes has been described previously (de Gortari \& Mengod 2010). Briefly, radioactive-labeled probes were diluted in a solution containing $50 \%$ formamide, $4 \times$ SSC ( $1 \times$ SSC: $150 \mathrm{mM} \mathrm{NaCl}, 15 \mathrm{mM}$ sodium citrate), Denhardt's solution $(0.02 \%$ Ficoll, $0.02 \%$ polyvinylpyrrolidone, $0.02 \% \mathrm{BSA}), 10 \%$ dextran sulfate, $1 \%$ sarkosyl, $20 \mathrm{mM}$ phosphate buffer $\mathrm{pH} 7.0), 250 \mu \mathrm{g} / \mathrm{mL}$ yeast tRNA and $500 \mu \mathrm{g} / \mathrm{mL}$ salmon sperm DNA, at a final concentration of 1.5-2 pmol. Fixed-tissues were incubated with hybridization solution and coverslipped with Parafilm (Bemis, Oshkosh, WI, USA). Once the incubation time was completed, sections were washed four times in $0.6 \mathrm{M} \mathrm{NaCl}, 10 \mathrm{mM}$ Tris- $\mathrm{HCl}(\mathrm{pH} 7.5)$ at $60^{\circ} \mathrm{C}$ during $45 \mathrm{~min}$ each time, and once in the same buffer at room temperature. After washings, sections were dipped into Kodak NTB autoradiography emulsion (Eastman Kodak Company, Rochester, NY, USA). Autoradiograms were developed with Kodak-D19 developer (Eastman Kodak Company) after a 3-week exposure at $4^{\circ} \mathrm{C}$, fixed in Ilford Hypam fixer (Polysciences Inc., Warrington, PA, USA), dehydrated in $70 \%$ and $100 \%$ ethanol and coverslipped with Entellan (Merck KGaA).

\section{Image analysis}

Autoradiograms were visualized with a Leica microscope DM500 (Leica Microsystems Inc.) under dark-field illumination, and images were obtained using a Leica ICC50 W camera and the $10 \times$ objective. Images were analyzed by computer measuring integrated optical density (IOD) of PVN signal using Image-Pro Plus 7.0 software (Media Cybernetics, Inc., Rockville, MD, USA). IOD of the background was measured for each image and subtracted from the PVN targets' signal IOD; three sections per PVN subcompartment per animal were analyzed for proTrh and for proCrf, and only mPVN was used for ISH analysis, with a final $n=4-5 /$ group.

\section{Real-time PCR (RT-PCR)}

Brains were hand dissected for RT-PCR analysis of ARC mRNAs (Npy, the long isoform of the leptin receptor $(\mathrm{Obrb})$ and suppressor of cytokine signaling 3 (SOCS3)) and PVN mRNAs (Trh, Crf, obrb and Socs3). PVN ( -0.84 to $-2.28 \mathrm{~mm}$ from bregma) and ARC ( -2.28 to $-3.48 \mathrm{~mm}$ from bregma) (Paxinos \& Watson 2005) were punch-dissected from frozen tissues using a $1 \mathrm{~mm}$ diameter sample corer and treated as described before for extraction of mRNA by guanidine thiocyanate method (Chomczynski \& Sacchi 1987). Briefly, $1.5 \mathrm{mg}$ of RNA was retro-transcribed with oligo-dT primer $(100 \mathrm{pmol} / \mathrm{mL}$; Biotechnology Institute of the UNAM, Cuernavaca, Morelos, Mexico) and M-MLV reverse transcriptase (Invitrogen) to obtain cDNA. ARC Npy, Socs3 and Obrb, in addition to PVN proTrh, proCrf, Obrb and Socs3 mRNA levels, were analyzed

Published by Bioscientifica Ltd 
Table 1 Weight of adrenal glands and adipose tissue subcompartments.

\begin{tabular}{|c|c|c|c|}
\hline & C & LPF & DPF \\
\hline Adrenal glands (g) & $0.04 \pm 0.003$ & $0.04 \pm 0.002$ & $0.04 \pm 0.002$ \\
\hline BAT (g) & $0.27 \pm 0.02$ & $0.27 \pm 0.02$ & $0.26 \pm 0.02$ \\
\hline Subcutaneous WAT (g) & $1.8 \pm 0.2$ & $2.1 \pm 0.2$ & $1.9 \pm 0.2$ \\
\hline Epididymal WAT (g) & $3.3 \pm 0.3$ & $3.7 \pm 0.4$ & $3.6 \pm 0.8$ \\
\hline Mesenteric WAT (g) & $2 \pm 0.1$ & $3.2 \pm 0.2^{*}$ & $2.5 \pm 0.3$ \\
\hline Perirenal retroperitoneal WAT (g) & $2.4 \pm 0.3$ & $4 \pm 0.5^{*}$ & $2.8 \pm 0.3$ \\
\hline
\end{tabular}

Weight of adrenal glands and adipose tissue subcompartments weight of 10-week-old animals subjected to tRF in prepuberal stage. BAT, brown adipose tissue; WAT, white adipose tissue. Data are expressed as the mean \pm S.E.M. in grams (adrenal glands, BAT and subcutaneous WAT: $n=22 / g$ roup; mesenteric, epididymal and perirenal retroperitoneal WAT: $n=6 /$ group). BAT, brown adipose tissue; C, control; DPF, darkness-phase fed animals; LPF, light-phase fed animals; WAT, white adipose tissue. One-way ANOVA followed by Tukey's post hoc test showed differences between groups.

$* P<0.05$ vs $C$.

by RT-PCR using Applied Biosystems reagents and equipment, comprising TaqMan Universal PCR Master Mix, a 7500 real-time PCR system, oligonucleotide primers (Npy, Rn014 10145_m1; Socs3, Rn00585674_ s1; Lepr, Rn01433205_m1; Trh, Rn00564880_m1; Crh, Rn01462137_m1; Actb, Rn00667869_m1). The $2-\Delta \Delta \mathrm{Ct}$ relative quantification method was used to calculate the fold-change in target mRNA expression, and beta actin was used as housekeeping gene to normalize RT-PCR data.

\section{Statistics}

Changes in food intake and body weight between groups along the 10 experimental weeks were analyzed by two-way ANOVA of repeated measures. Weight of adrenal glands and adipose tissue subcompartments, serum hormones' levels, proTrh and proCrf mRNA expression in PVN subdivisions data were analyzed by one-way ANOVA. Two-way ANOVA was performed to compare body weight loss, changes in food intake after refeeding, the weight of their adrenal glands and adipose tissue subcompartments, and their mRNA expression of peptides in hypothalamic PVN and ARC by RT-PCR, between animals treated with veh or leptin i.p. after 48 -h fasting. When $P<0.05$, we performed Tukey's post hoc test.

\section{Results}

\section{Body weight, food intake and adipose tissue weight}

Body weight of LPF animals increased 11\% from week 5 in comparison with DPF group and 9\% and 12\% from week 6 when compared with $\mathrm{C}$ and DPF groups; such increase was maintained until week 10 of the experi- ment, reaching a 17\% increase at ninth week (Fig. 1B). Two-way ANOVA of repeated measures showed that there was a significant effect of feeding schedule $\left(F_{(2,736)}=37.46, \quad P<0.0001\right), \quad$ age $\quad\left(F_{(7,736)}=801.54\right.$, $P<0.0001)$ and the interaction between variables $\left(F_{(14,736)}=1.71, \quad P<0.05\right)$. In a similar fashion, food intake of LPF group increased an average of 12\% along the experiment in comparison with $\mathrm{C}$ and DPF animals (Fig. 1C). Two-way ANOVA of repeated measures revealed an effect of feeding schedule $\left(F_{(2,672)}=33.69\right.$, $P<0.0001)$ and age $\left(F_{(6,672)}=165.11, P<0.0001\right)$.

Adrenal glands, BAT, subcutaneous and epididymal subcompartments of WAT showed no significant differences among groups (Table 1). In contrast, LPF group's mesenteric and perirenal retroperitoneal WAT weight increased to $154 \%$ and to $173 \%$, respectively, when compared with C animals (100\%) (Table 1; mesenteric: $F_{(2,15)}=10.019$, $P<0.01$; perirenal retroperitoneal: $\left.F_{(2,15)}=5.566, P<0.05\right)$.

\section{Serum hormones' concentration}

Although $\mathrm{T}_{4}$ serum concentration was reduced by $21 \%$ in LPF animals compared with $\mathrm{C}\left(F_{(2,30)}=3.727, P<0.05\right), \mathrm{T}_{3}$

Table 2 Serum hormones' content.

\begin{tabular}{|c|c|c|c|}
\hline & C & LPF & DPF \\
\hline$T_{4}(\mu g / d L)$ & $11.9 \pm 0.8$ & $9.3 \pm 0.8^{*+}$ & $11.5 \pm 0.5$ \\
\hline $\mathrm{T}_{3}(\mathrm{ng} / \mathrm{dL})$ & $100.6 \pm 5.5$ & $107.7 \pm 4.1$ & $93.1 \pm 3.9$ \\
\hline Insulin (ng/mL) & $0.6 \pm 0.05$ & $0.9 \pm 0.08 *$ & $0.7 \pm 0.04$ \\
\hline $\begin{array}{l}\text { Corticosterone } \\
(\mathrm{ng} / \mathrm{mL})\end{array}$ & $248.3 \pm 71.4$ & $667.4 \pm 110^{*+}$ & $205 \pm 81.8$ \\
\hline Leptin $(\mathrm{pg} / \mathrm{mL})$ & $1273.7 \pm 124.3$ & $1839.3 \pm 211^{*+}$ & $1306.3 \pm 150.6$ \\
\hline
\end{tabular}

Hormones' determinations were performed on serum of 10-week-old animals subjected to tRF in prepuberal stage (PN21-PN35). The number of animals analyzed was $n=6 /$ group. Values are expressed as the mean \pm S.E.M. C, control group; DPF, darkness-phase fed group; LPF, light-phase fed group. One-way ANOVA followed by Tukey's post hoc test showed differences between groups. ${ }^{*} P<0.05$ vs $C_{i}+P<0.05$ vs DPF.

Published by Bioscientifica Ltd 
content showed no differences between groups (Table 2). Insulin, corticosterone and leptin serum concentrations had a 1.4-fold, 2.7-fold and 1.4-fold increase, respectively, in LPF animals in comparison with $\mathrm{C}$ group and a 3.3fold corticosterone increase compared with DPF animals (Table 2; insulin: $F_{(2,24)}=5.273, P<0.05$; corticosterone: $F_{(2,16)}=8.092, P<0.01$; leptin: $\left.F_{(2,45)}=3.660, P<0.05\right)$.

\section{proTrh and procrf mRNA expression in PVN by ISH histochemistry}

proTrh mRNA expression from non-hypophysiotropic aPVN neurons showed no significant differences in animals either fed in light or in darkness phase (Fig. 2A, B, C, J). Hypophysiotropic TRHergic neurons of medial and

\section{pro TRH}
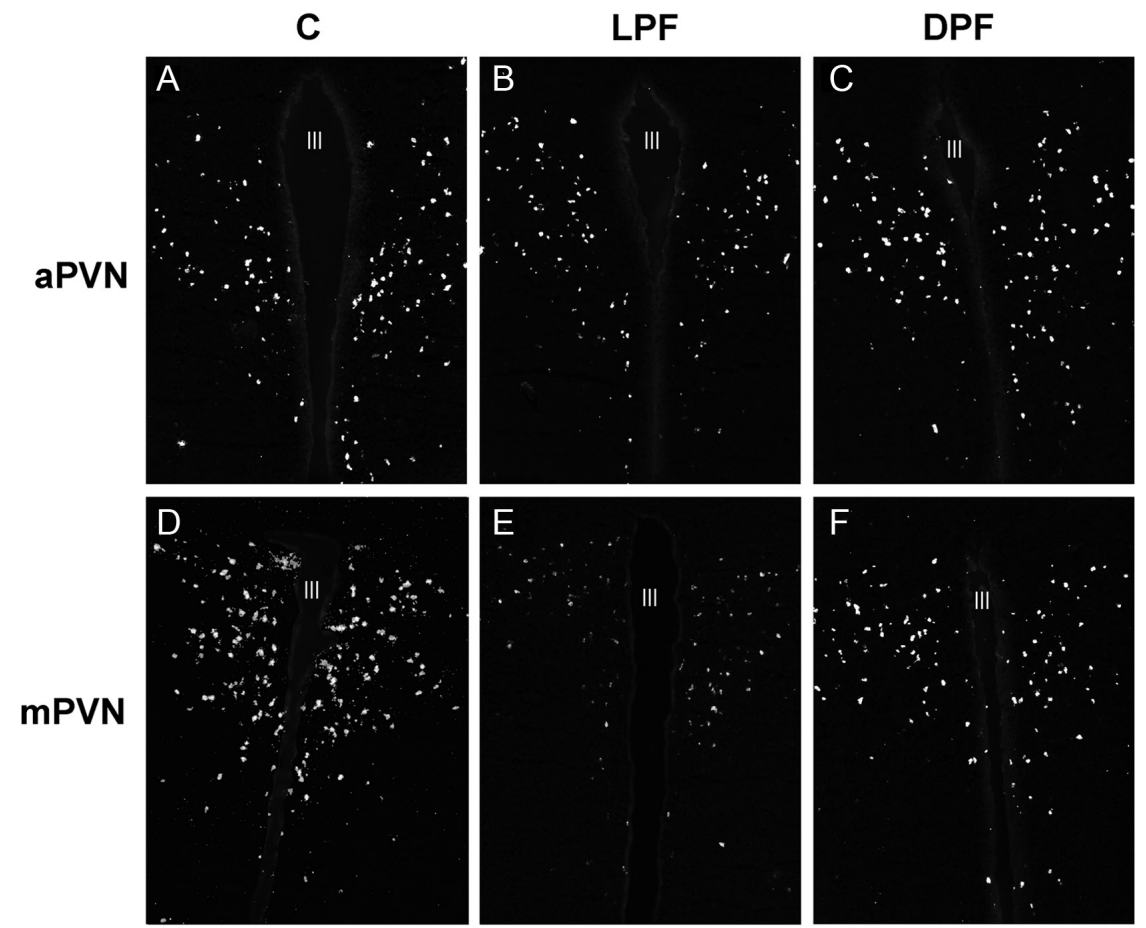
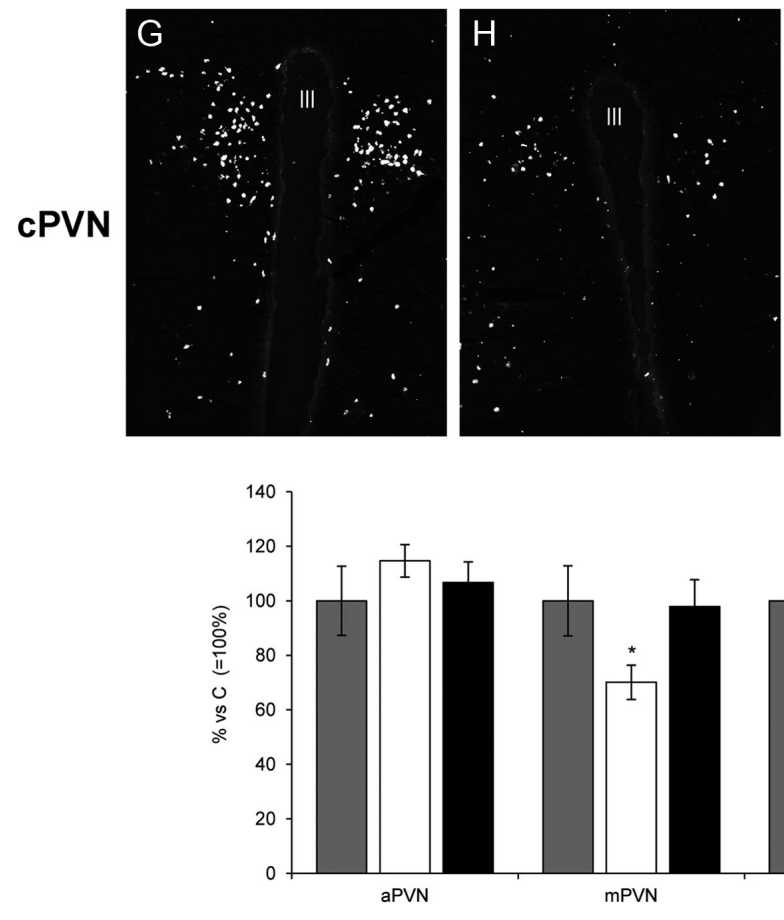

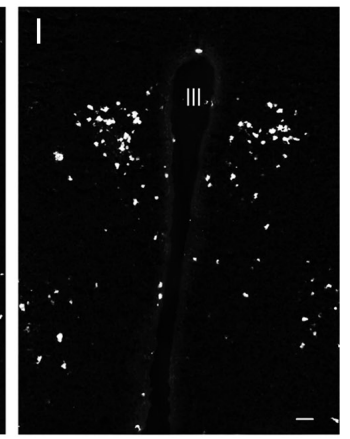

$\square C \quad$ QLPF $\square D P F$
Figure 2

proTrh mRNA expression in PVN subcompartments. (A-J) Low-power 10x-magnification dark-field illumination photomicrographs of representative samples of radioactive-labeled proTRH mRNA by ISH of aPVN of $C(A)$, LPF (B) and DPF (C), of mPVN of C (D), $\operatorname{LPF}(\mathrm{E})$ and DPF (F), and of CPVN of C (G), LPF (H) and DPF (I) groups. III: third ventricle. Scale bar $50 \mu \mathrm{m}$. (J) Expression of proTRH in PVN subcompartments of C, LPF and DPF animals. Control (C), light-phase feeding (LPF) and darkness-phase feeding (DPF) groups. Data are expressed as the mean \pm S.E.M. of percentage of $C$ values ( $100 \% ; n=4-5 /$ group). One-way ANOVA followed by Tukey's post hoc test showed differences between groups, ${ }^{*} P<0.05$ vs $C$; $\# P<0.05$ vs DPF. 

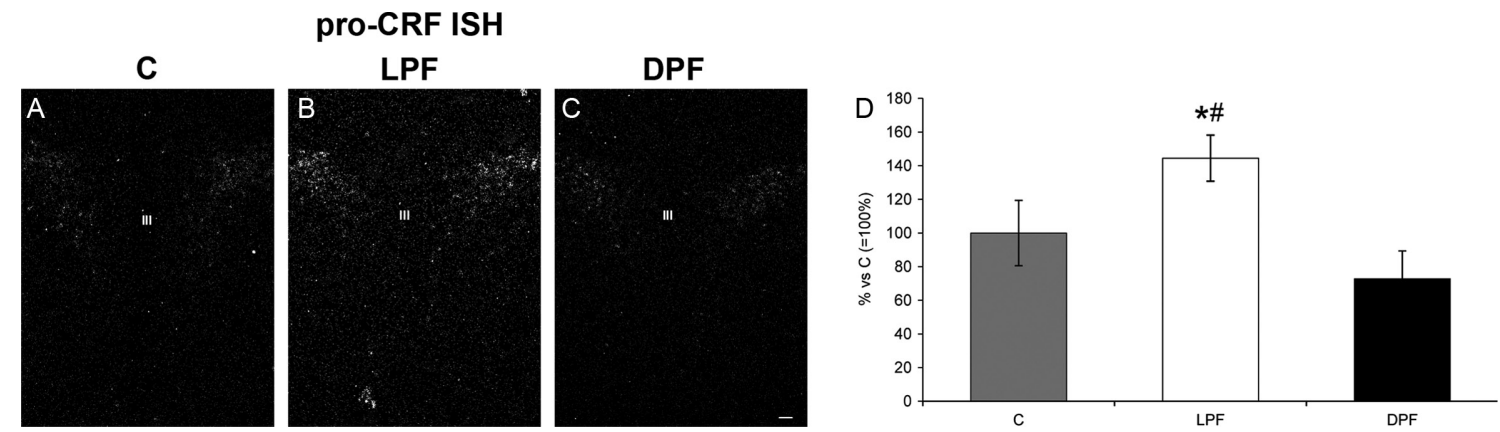

Figure 3

proCRF mRNA expression in PVN. (A-C) Low-power 10x magnification dark-field illumination photomicrographs of representative samples of radioactive-labeled proCRF mRNA by ISH in PVN of C (A), LPF (B) and DPF (C) groups. III: third ventricle. Scale bar $50 \mu \mathrm{m}$. (D) Expression of proCRF in PVN of C, LPF and DPF animals. Control (C), light-phase feeding (LPF), darkness-phase feeding (DPF) groups. Data are expressed as the mean \pm s.E.M. of percentage of $C$ values (100\%; $n=4-5 /$ group). One-way ANOVA followed by Tukey's post hoc test showed differences between groups, * $P<0.05$ vs $C$; ${ } P<0.05$ vs DPF

caudal PVN direct HPT axis function, and proTrh mRNA expression was decreased in LPF group to $70 \%$ in $\mathrm{mPVN}$ $\left(F_{(2,19)}=4.43, P<0.05\right)$, whereas in cPVN decreased to $56 \%$ in comparison with those of C (100\%) (Fig. 2D, E, F, G, $\left.\mathrm{H}, \mathrm{I}, \mathrm{J} ; F_{(2,18)}=4.969, P<0.05\right)$. proCrf mRNA expression increased to $144 \%$ in PVN of LPF animals in comparison with that of C (100\%) and DPF groups (Fig. 3A, B, C, D; $\left.F_{(2,10)}=6.608, P<0.05\right)$.

\section{Effect of 48-h fasting and leptin administration on body weight and food intake after 6-h of refeeding}

As LPF rats showed an increase in body weight, visceral WAT weight and in serum leptin levels, HPT axis should be activated promoting and increased metabolic rate, but instead, hypophysiotropic PVN proTrh mRNA expression was decreased. We exposed animals of the three groups to a 48-h fasting in addition to veh or leptin i.p. administration and measured hypothalamic feeding-involved neuropeptides' expression as well as, leptin signaling molecules mRNA levels. Fasted animals treated either with veh or leptin decreased their body weight in a similar manner between groups (Fig. 4A); the $\% \Delta$ in body weight loss was as follows: $6.5 \%$, 9.6\% and 7.3\% in C-veh, LPF-veh and DPF-veh groups and $8.5 \%, 8.8 \%$ and $8.4 \%$ in C-leptin, LPF-leptin and DPF-leptin animals, respectively, compared with their basal body weight before fasting, but no significant differences were found.

After $48 \mathrm{~h}$ of fasting and treatment with either veh or leptin, animals were refed for $6 \mathrm{~h}$ and their food intake was registered. As expected, data showed that leptin treatment decreased food intake to $78 \%$ in C-leptin and to $84 \%$ in DPF-leptin groups when compared with their respective veh groups (100\%) (Fig. 4B). On the other hand, LPF-leptin animals ate 84\% more than C-leptin animals (Fig. 4B). Two-way ANOVA showed significant differences between groups $\left(F_{(2,28)}=34.498, P<0.001\right)$ and in the interaction between groups and treatment $\left(F_{(2,28)}=14.088, \quad P<0.001\right)$. Concerning adrenals and adipose tissue subcompartments weight, we found that in LPF animals, the weight of mesenteric and perirenal retroperitoneal WAT was higher than $\mathrm{C}$ animals as stated before (Table 3). The weight of adrenal glands and the rest of adipose tissue subcompartments did not show significant changes between groups or treatment (Table 3). Two-way ANOVA showed differences only between groups in mesenteric WAT $\left(F_{(2,28)}=4.726, \quad P<0.05\right)$ and perirenal retroperitoneal WAT $\left(F_{(2,28)}=4.075, P<0.05\right)$, but not in treatment or in the interaction of variables.

\section{Effect of 48-h fasting and leptin administration on hypothalamic mRNA peptides expression}

Arcuate nucleus LPF animals administered with veh showed the reported ARC response to a metabolic challenge such as fasting; we found that Npy mRNA expression in LPF group was increased to $177 \%$ to that of C- and DPF-veh animals. Npy mRNA increase could be implicated in the higher chow consumption as well as in the higher body weight that LPF rats presented (Fig. 5A). As expected, leptin administration decreased Npy mRNA expression in C and DPF animals to $56 \%$ and $65 \%$, respectively. In contrast, Npy mRNA content of LPF group administered with leptin did not change compared with LPF-veh (Fig. 5A). Two-way ANOVA

Published by Bioscientifica Ltd. 
A
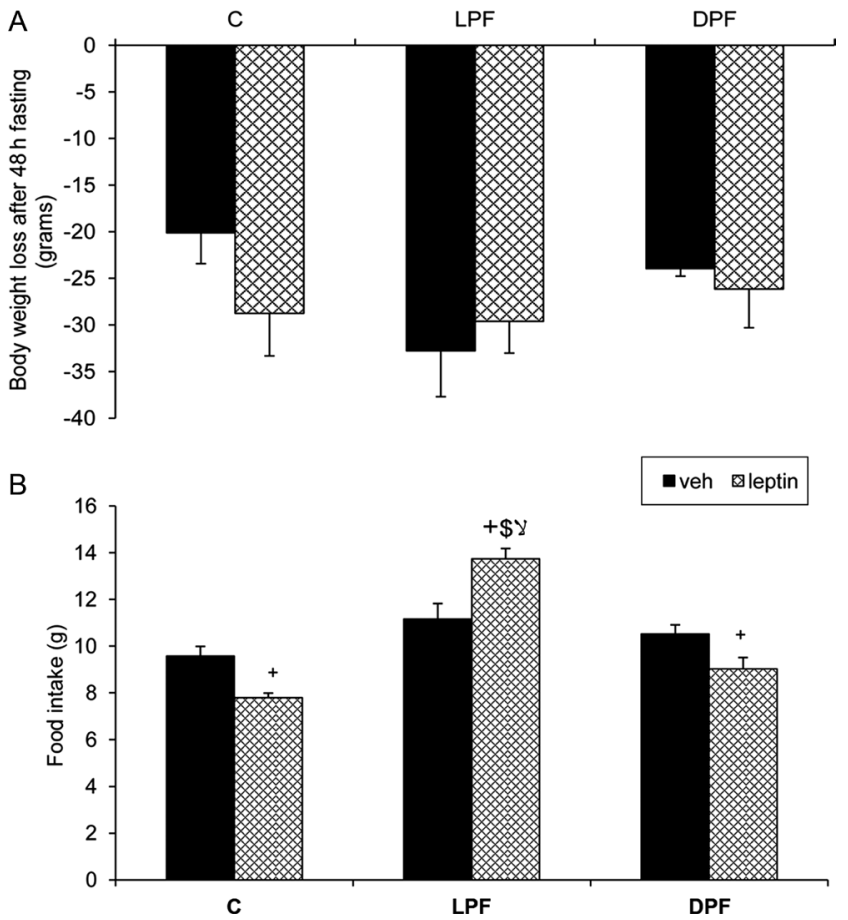

Figure 4

Body weight loss and food intake of adult C, LPF and DPF fasted animals administered i.p. with veh or leptin. (A) Body weight loss before 48-h fasting of ten-week-old C, LPF and DPF groups administered with veh or recombinant mouse leptin $(0.1 \mu \mathrm{g} / \mathrm{g}$ B.W. $)$. Values are expressed as the mean \pm S.E.M. of grams of body weight loss ( $n=5-6 /$ group). (B) Food intake of C, LPF and DPF 48-h fasted groups administered with veh or recombinant mouse leptin $(0.1 \mu \mathrm{g} / \mathrm{g}$ B.W. $)$, allowed to fed for $6 \mathrm{~h}$ after fasting. Values are expressed as the mean \pm S.E.M. of grams of food consumed ( $n=5-6 /$ group). Two-way ANOVA followed by Tukey's post hoc test showed differences between groups, $+P<0.05$ vs their respective veh groups; ${ }^{\$} P<0.05$ vs $C$-leptin, $\gamma P<0.05$ vs DPF-leptin.

indicated that differences were within groups $\left(F_{(2,25)}=10.790, P<0.001\right)$ and treatment $\left(F_{(1,25)}=6.490\right.$, $P<0.05)$, but there was no interaction.

Impairment of leptin signaling was revealed by a 205\% increase of Socs 3 mRNA content in LPF-veh animals when compared with C-veh mRNA expression (100\%: Fig. 5B), which might be associated with the increased expression of $N p y$ in the same group (Fig. 5A). Peripheral administration of leptin increased Socs3 expression in C and DPF groups, but not in LPF animals, which maintained the same increase as veh-administered animals (Fig. 5B), revealing an impairment in leptin signaling in the ARC neurons of LPF animals. Two-way ANOVA showed a significant effect of group $\left(F_{(2,24)}=3.879, P<0.05\right)$ and treatment $\left(F_{(1,24)}=6.590, P<0.05\right)$, and no significant differences in the interaction of the variables. Additionally, as expected Obrb mRNA levels increase in all groups in response to fasting and leptin administration, but no differences in expression between fasted groups (Fig. 5C).

Paraventricular nucleus Despite veh-administered animals were under a 48-h fasting challenge, proTrh mRNA levels in LPF group showed a more pronounced tendency to decrease than C and DPF animals (Fig. 5D). Interestingly, leptin administration did not increase proTrh expression in LPF as it did in C and DPF groups compared with their veh-administered counterparts (Fig. 5D). Two-way ANOVA showed a significant effect of group $\left(F_{(2,28)}=19.992, P<0.001\right)$, treatment $\left(F_{(1,28)}=9.813, P<0.01\right)$ and the interaction of the variables $\left(F_{(2,28)}=4.418, P<0.05\right)$. As expected, proCrf expression diminished in C- (18\%) and DPF-veh (47\%) vs C-fed groups (100\%); a reduction not seen in LPF-veh animals whose proCrf mRNA levels increased to $181 \%$ (Fig. 5E). Leptin administration restored proCrf mRNA content to C-fed levels in C- (104\%) and DPF-leptin (109\%) animals, but in LPF-leptin group, it did not increase beyond LPF-veh proCrf expression (168\%) (Fig. 5E). Two-way ANOVA showed effect of group $\left(F_{(2,22)}=4.990, P<0.01\right)$. Furthermore, $\mathrm{Obrb}$ and

Table 3 Effect of 48-h fasting and leptin treatment in weight of adrenals and adipose tissue subcompartments.

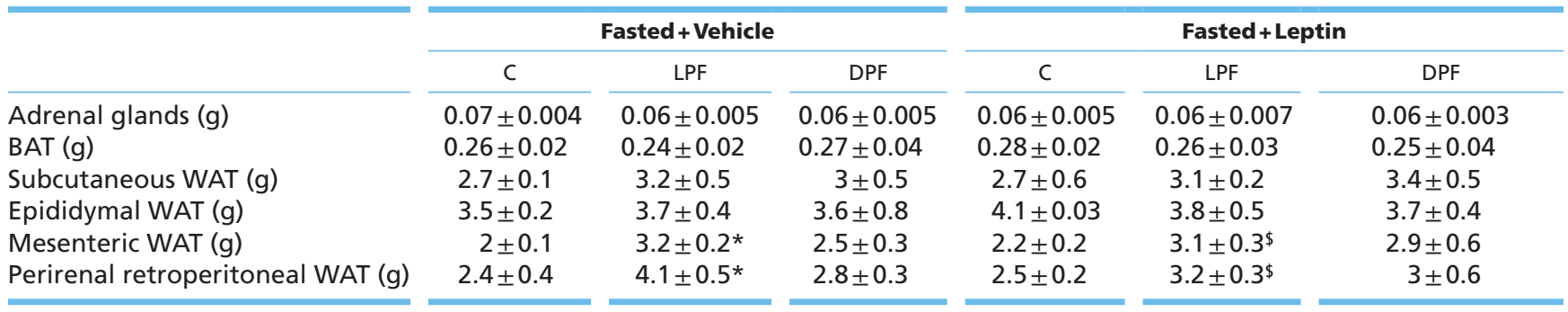

Weight of adrenal glands and adipose tissue subcompartments of 10-week-old animals subjected to tRF in prepuberal stage that were challenged with a 48-h fasting with i.p. administration of veh or recombinant mouse leptin $(0.1 \mu \mathrm{g} / \mathrm{g} \mathrm{B.W}$.) twice a day during the $48 \mathrm{~h}$ of fasting. After that, animals were allowed to eat for $6 \mathrm{~h}$ and then killed, and adrenal glands and adipose tissue subcompartments were dissected and weighted. Values are the mean \pm s.E.M. in grams, $n=5-6 /$ group. BAT, brown adipose tissue; C, control group; DPF, darkness-phase fed group; LPF, light-phase fed group; WAT, white adipose tissue. Two-way ANOVA followed by Tukey's test when $P<0.05$ was performed, $* P<0.05$ vs C-veh, $\$ P<0.05$ vs C-leptin. 

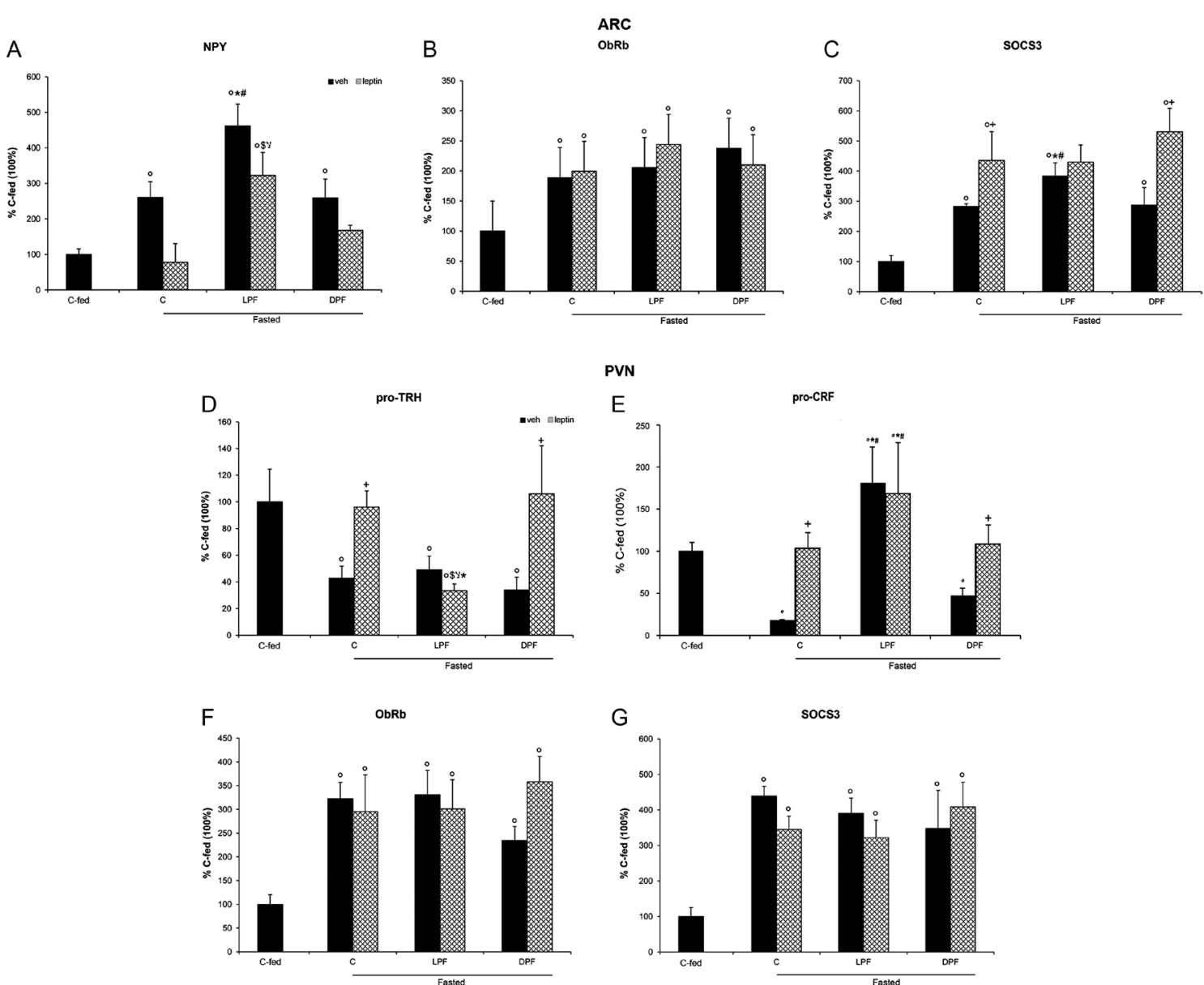

Figure 5

Hypothalamic ARC and PVN peptides' expression of fasted C, LPF and DPF adult animals administered with veh or recombinant mouse leptin $(0.1 \mu \mathrm{g} / \mathrm{g}$ B.W.). Data are mRNA expression by real-time PCR of each studied amplicon after being normalized against actin mRNA expression by the $2^{-\triangle \Delta C t}$ relative quantization method. ARC NPY (A), ObRb (B), SOCS3 (C) and PVN proTRH (D), proCRF (E) ObRb (F) and SOCS3 (G) were examined. Values are expressed as the mean \pm S.E.M. of percentage of C-fed values ( $100 \% ; n=5-6 /$ group). Two-way ANOVA followed by Tukey's post hoc test showed differences between groups, ${ }^{\circ} P<0.05$ vs $C$-fed; $+P<0.05$ vs their respective veh groups; ${ }^{*} P<0.05$ vs $C$-veh; $\# P<0.05$ vs $D P F-$ veh; $\$ P<0.05$ vs $C$-leptin, $\gamma P<0.05$ vs DPF-leptin.

Socs3 mRNA expression in PVN was not altered neither by treatment nor by group (Fig. 5F, G).

\section{Discussion}

Prepuberty is a critical window of neuronal development, susceptible to serum hormones' levels fluctuations, modifying the response of different hypothalamic networks to a positive energy balance, as a consequence of alterations in feeding patterns. Such alterations can lead to an impaired activity of feeding-regulatory signals and consequently to hyperphagia and overweight that might last until adulthood. Altering feeding patterns during prepuberty could impair hypothalamic neuronal development, and consequently, feeding regulation.
Therefore, we studied the effect of a time-restricted feeding schedule during prepuberal stage on adult animals' food intake, body weight and expression of hypothalamic peptides involved in regulation of energy homeostasis by controlling HPA and HPT axis function.

Two hours before lights are off, ad libitum-fed animals, present locomotion activation (food anticipatory activity (FAA)) along with increased serum GC content and ARC Npy mRNA facilitating food intake consumption. Afterwards, a counter-regulatory stimulation of anorexigenic signals is presented; after a meal, animals show high insulin and leptin serum content, as well as, ARC Pomc mRNA levels. This shift from anabolic to catabolic pathways allows the energy homeostasis and regulation of body weight. Thus, uncoupling the moment of food presentation from

Published by Bioscientifica Ltd. 
the light/darkness cycle by shifting food availability to the resting (light) phase, alters the energy expenditure relation with food intake. When animals are subjected to a tRF, the onset of FAA and activation of orexigenic pathways are changed toward the moment of food presentation, which uncouples central and peripheral clocks; thus, feeding in the light phase induces leptin and insulin release in an unusual circadian time, with a consequent activation of brain peptides' synthesis that leads to an aberrant control of energy homeostasis.

Prepuberal darkness-phase feeding, which had a short delay in the offering of food in relation to the start of the darkness period (food available at 2300 instead of $1900 \mathrm{~h}$ ) showed no changes in any of the evaluated parameters when compared with controls. This suggested that the DPF schedule during prepuberty did not change their food intake and allowed them to adapt to the subsequent 24-h ad libitum food intake schedule up to adulthood. As their tRF was limited in the darkness phase, FAA and the orexigenic pathways seemed to peak at a similar moment of the day than that of $\mathrm{C}$ ad libitum-fed animals during prepuberty, which was evinced by their unchanged food intake and body weight throughout their lifespan.

In contrast, shifting the feeding schedule to the light phase during prepuberty, produced hyperphagia and overweight in LPF group, which seemed associated to their HPA axis hyperactivity, as has been described before in early-stage stressed adult animals and humans (Dallman et al. 2003, La Fleur et al. 2004); our results implied that prepuberal light phase feeding could be acting as a chronic stressor. Impaired regulation of the HPA axis was evinced by the increased PVN Crf mRNA, along with a higher GC concentration, which seemed to show a blocked negative feedback of GC into the PVN.

The higher GC content could be related to food intake stimulation of LPF because the i.p. injection of the synthetic GC dexamethasone (DEX), increases the orexigenic effects of factors and pathways, such as those of ARC NPY/AgRP (Shimizu et al. 2008) and AMPK, respectively (Savontaus et al. 2002, Konno et al. 2008, Shimizu et al. 2008). In fact, the AMPK pathway has been involved in regulation of both circadian and metabolic-induced genes' expression (Lopez et al. 2008, Lamia et al. 2009, de Andrade et al. 2015); thus, its function might be relevant for LPF-related metabolic and neuroendocrine alterations, and it would be interesting to study its role in LPF impairments. This could be possible as before the presentation of a meal regardless of the light/darkness period, NPY is released into the PVN, and the serum GC content increases
(Honma et al. 1983, Kalra et al. 1991), suggesting that the chronic elevation in GC of light-phase feeding schedule, caused their hyperphagia through activating ARC NPY pathway.

The sustained high GC levels also seemed responsible for the increased visceral WAT depots of LPF animals (Rebuffe-Scrive et al. 1992, Campbell et al. 2011). This is supported by the activation of lipogenic genes in visceral fat pads and the differentiation of pre-adipocytes to adipocytes (Zilberfarb et al. 2001) by peripheral DEX administration (Marin et al. 1992, Chimin et al. 2014). This is also supported by the fact that in Cushing's disease, energy deposits are mainly accumulated in visceral adipose tissue (Geer et al. 2010) and that salivary GC concentration is positively associated with visceral adiposity (Epel 2009).

The high GC serum content induced by the prepuberal light-phase feeding could reduce neuronal sensitivity to leptin and insulin effects in this group (Zakrzewska et al. 1997, Asensio et al. 2004). Therefore, we aimed to study an impaired leptin's signaling and its effects on ARC Npy and PVN Trh mRNAs expression to explain hyperphagia of LPF animals despite their hyperleptinemia.

In this study, light phase feeding induced a dysfunction of HPT axis as $\mathrm{T}_{4}$ concentration decreased in LPF animals, which hampered $T_{3}$ to increase as expected. Previous reports show that obese patients present an enhanced HPT axis activity that is evinced by their higher $\mathrm{T}_{3}$ serum levels (Reinehr 2010), whereas rodents had higher PVN Trh mRNA expression and circulating $\mathrm{T}_{3}$ (Perello et al. 2010, Franco et al. 2012). Those changes promote higher energy expenditure. In contrast, our results showed that light phase feeding during prepuberty did not increase HPT axis function.

Furthermore, Trh mRNA levels decreased in hypophysiotropic neurons of $\mathrm{mPVN}$ and $\mathrm{cPVN}$ in LPF group, despite their overweight and hyperleptinemia that should enhance TRH transcription (Legradi et al. 1997). The aforementioned results are in accordance to those of overweight early-overfed animals, whose Trh expression in hypophysiotropic neurons of mPVN is also decreased (Arechiga-Ceballos et al. 2014). This lack of adaptation might decrease rats' metabolic rate, promoting excessive energy storage as adipose tissue. The decreased expression of hypophysiotropic Trh could be the result of enhanced levels of GC, which repress peptide's transcription through a glucocorticoid-responsive element on TRH gene's promoter (Kakucska et al. 1995, Lee et al. 1996). Additional experiments would be relevant to explore this idea.

Published by Bioscientifica Ltd 
We expected that the expression of Trh from feeding regulating-involved neurons of the aPVN subcompartment were increased in LPF animals, given the known anorexigenic actions of the synthesized TRH in that PVN subregion (Wittmann et al. 2009, AlvarezSalas et al. 2012). As Trh mRNA levels did not change despite of the positive energy balance in LPF rats, it is likely that they had an impaired adaptation to their high lipids deposits, contributing to the display of their hyperphagia.

As feeding in light-phase during prepuberty promoted hyperphagia despite the hyperleptinemia, we hypothesized that prepuberal light-phase feeding could result in leptin resistance, which besides was supported by the blunted Trh expression, which should be upregulated by leptin. To test our hypothesis, we injected i.p. vehicle or leptin to 48-h fasted ten-week-old animals of all groups. Our rationale was that since after fasting, the low leptin levels are responsible for the decreased PVN Trh mRNA content and for the high ARC NPY expression (Marks et al. 1992, Legradi et al. 1997). Leptin administration should be able to reverse those changes in fasted animals if its signaling is properly functional.

Fasting induced the expected loss in body weight and adipose tissue depots in all groups. Also, we observed the expected PVN Trh and Crf expression decrease, as well as the upregulation in ARC Npy, PVN and ARC Obrb and Socs 3 mRNA content (Mitchell et al. 2009, ArechigaCeballos et al. 2014). It was noteworthy that LPF-vehfasted group had a further increase in ARC $N p y$ and Socs3 than in fasted DPF-veh and control-veh. SOCS3 is a protein that inhibits the signal transduction of leptin; thus, its chronic increment is considered as indicative of hormone's resistance (Bjorbaek et al. 1998). Therefore, our results supported an impaired ARC signaling of leptin due to feed prepuberal animals during the light period. We corroborated this with the leptin administration to light-phase-fed prepuberal animals that were fasted in adulthood, whose ARC Npy expression did not decrease, and PVN Trh mRNA levels did not increase as expected by hormone's effects.

PVN Trh expression is known to be upregulated by leptin through two different pathways. The direct one is due to leptin's action on ObRb signaling in the PVN that upregulates Trh transcription. The indirect one involves leptin effects on ARC Npy and alpha Msh expression and release. This allows PVN TRH synthesis to be activated because NPY exerts negative actions on its synthesis and alpha MSH enhances it (Fekete et al. 2002, Sarkar et al. 2002).
We here evinced that light-phase feeding during prepuberty impaired central leptin actions: ARC Npy expression did not decrease, and we observed a sustained elevation of that of Socs3. Leptin signaling in the PVN seemed functional as Socs 3 was similarly changed to that of DPF and controls. We thus assumed that the lack of increase in PVN Trh mRNA levels after leptin administration in LPF rats was due to their impaired leptininduced downregulation of Npy in the ARC. This could be responsible for their hyperphagia and overweight, as well as for the lack of adaptation of the HPT axis to their positive energy balance. It is likely that leptin resistance was related to the high GC circulating levels, as has been described (Dallman et al. 2004).

Finally, we confirmed an impairment of leptin signaling as well as HPA axis hyperactivity by the high proCrf expression in LPF-veh fasted group and by the lack of a further increase in LPF-leptin rats.

In conclusion, prepuberal animals subjected to tRF during light phase showed impairment in energy homeostasis regulatory mechanisms that persisted until adulthood. Their overweight and hyperphagia could be the result of leptin resistance in the ARC.

Our results support that eating habits and regular feeding patterns in the activity phase in childhood may assure an adequate programming of the neuroendocrine axes function by the rest/activity cycle-induced release of peripheral hormones that coordinate energy homeostasis avoiding metabolic alterations later in life.

\section{Declaration of interest}

The authors declare that there is no conflict of interest that could be perceived as prejudicing the impartiality of the research reported.

\section{Funding}

This work was supported by Conacyt grant CB2010/128316 (P G).

\section{Acknowledgements}

The authors wish to thank J L Calderón and R Cardoso for their help with illustrations.

\section{References}

Ahima RS, Kelly J, Elmquist JK \& Flier JS 1999 Distinct physiologic and neuronal responses to decreased leptin and mild hyperleptinemia. Endocrinology 140 4923-4931. (doi:10.1210/en.140.11.4923)

Ahima RS, Prabakaran D \& Flier JS 1998 Postnatal leptin surge and regulation of circadian rhythm of leptin by feeding. Implications for energy homeostasis and neuroendocrine function. Journal of Clinical Investigation 101 1020-1027. (doi:10.1172/JCI1176)

Published by Bioscientifica Ltd. 
Al-Naimi S, Hampton SM, Richard P, Tzung C \& Morgan LM 2004 Postprandial metabolic profiles following meals and snacks eaten during simulated night and day shift work. Chronobiology International 21 937-947. (doi:10.1081/CBI-200037171)

Alvarez-Salas E, Aceves C, Anguiano B, Uribe R, García-Luna C, Sánchez E \& de Gortari P 2012 Food-restricted and dehydrated-induced anorexic rats present differential TRH expression in anterior and caudal PVN. Role of type 2 deiodinase and pyroglutamyl aminopeptidase II. Endocrinology 153 4067-4076. (doi:10.1210/en.2011-2011)

Alvarez-Salas E, Mengod G, Garcia-Luna C, Soberanes-Chavez P, Matamoros-Trejo G \& de GP 2016 Mct8 and trh co-expression throughout the hypothalamic paraventricular nucleus is modified by dehydration-induced anorexia in rats. Neuropeptides 56 33-40. (doi:10.1016/j.npep.2015.11.001)

Amani R \& Gill T 2013 Shiftworking, nutrition and obesity: implications for workforce health - a systematic review. Asia Pacific Journal of Clinical Nutrition 22 505-515. (doi:10.6133/apjcn.2013.22.4.11)

Antunes LC, Levandovski R, Dantas G, Caumo W \& Hidalgo MP 2010 Obesity and shift work: chronobiological aspects. Nutrition Research Reviews 23 155-168. (doi:10.1017/S0954422410000016)

Arechiga-Ceballos F, Alvarez-Salas E, Matamoros-Trejo G, Amaya MI, Garcia-Luna C \& de GP 2014 Pro-TRH and pro-CRF expression in paraventricular nucleus of small litter-reared fasted adult rats. Journal of Endocrinology 221 77-88. (doi:10.1530/JOE-13-0458)

Asensio C, Muzzin P \& Rohner-Jeanrenaud F 2004 Role of glucocorticoids in the physiopathology of excessive fat deposition and insulin resistance. International Journal of Obesity and Related Metabolic Disorders 28 (Supplement 4) S45-S52. (doi:10.1038/sj.ijo.0802856)

Baquero AF, de Solis AJ, Lindsley SR, Kirigiti MA, Smith MS, Cowley MA, Zeltser LM \& Grove KL 2014 Developmental switch of leptin signaling in arcuate nucleus neurons. Journal of Neuroscience $\mathbf{3 4}$ 9982-9994. (doi:10.1523/JNEUROSCI.0933-14.2014)

Bjorbaek C, Elmquist JK, Frantz JD, Shoelson SE \& Flier JS 1998 Identification of SOCS-3 as a potential mediator of central leptin resistance. Molecular Cell 1 619-625. (doi:10.1016/S10972765(00)80062-3)

Bjorntorp P 2001 Do stress reactions cause abdominal obesity and comorbidities? Obesity Reviews 2 73-86. (doi:10.1046/j.1467789x.2001.00027.x)

Bodosi B, Gardi J, Hajdu I, Szentirmai E, Obal F Jr \& Krueger JM 2004 Rhythms of ghrelin, leptin, and sleep in rats: effects of the normal diurnal cycle, restricted feeding, and sleep deprivation. American Journal of Physiology: Regulatory, Integrative and Comparative Physiology 287 R1071-R1079. (doi:10.1152/ajpregu.00294.2004)

Bojanowska E \& Nowak A 2007 Interactions between leptin and exendin-4, a glucagon-like peptide-1 agonist, in the regulation of food intake in the rat. Journal of Physiology and Pharmacology $\mathbf{5 8}$ 349-360.

Bouret SG, Draper SJ \& Simerly RB 2004 Trophic action of leptin on hypothalamic neurons that regulate feeding. Science 304 108-110. (doi:10.1126/science.1095004)

Bray MS, Ratcliffe WF, Grenett MH, Brewer RA, Gamble KL \& Young ME 2013 Quantitative analysis of light-phase restricted feeding reveals metabolic dyssynchrony in mice. International Journal of Obesity $\mathbf{3 7}$ 843-852. (doi:10.1038/ijo.2012.137)

Campbell JE, Peckett AJ, D'souza AM, Hawke TJ \& Riddell MC 2011 Adipogenic and lipolytic effects of chronic glucocorticoid exposure. American Journal of Physiology: Cell Physiology 300 C198-C209. (doi:10.1152/ajpcell.00045.2010)

Cheung CC, Clifton DK \& Steiner RA 1997 Proopiomelanocortin neurons are direct targets for leptin in the hypothalamus. Endocrinology 138 4489-4492. (doi:10.1210/endo.138.10.5570)

Chimin P, Farias TS, Torres-Leal FL, Bolsoni-Lopes A, Campana AB, Andreotti S \& Lima FB 2014 Chronic glucocorticoid treatment enhances lipogenic activity in visceral adipocytes of male Wistar rats. Acta Physiologica 211 409-420. (doi:10.1111/apha.12226)
Chomczynski P \& Sacchi N 1987 Single-step method of RNA isolation by acid guanidinium thiocyanate-phenol-chloroform extraction. Analytical Biochemistry 162 156-159. (doi:10.1016/00032697(87)90021-2)

Cone RD, Cowley MA, Butler AA, Fan W, Marks DL \& Low MJ 2001 The arcuate nucleus as a conduit for diverse signals relevant to energy homeostasis. International Journal of Obesity and Related Metabolic Disorders 25 (Supplement 5) S63-S67. (doi:10.1038/sj.ijo.0801913)

Dallman MF, Akana SF, Strack AM, Scribner KS, Pecoraro N, La Fleur SE, Houshyar H \& Gomez F 2004 Chronic stress-induced effects of corticosterone on brain: direct and indirect. Annals of the New York Academy of Sciences 1018 141-150. (doi:10.1196/annals.1296.017)

Dallman MF, Pecoraro N, Akana SF, La Fleur SE, Gomez F, Houshyar H, Bell ME, Bhatnagar S, Laugero KD \& Manalo S 2003 Chronic stress and obesity: a new view of 'comfort food'. PNAS 100 11696-11701. (doi:10.1073/pnas.1934666100)

de Andrade IS, Zemdegs JC, de Souza AP, Watanabe RL, Telles MM, Nascimento CM, Oyama LM \& Ribeiro EB 2015 Diet-induced obesity impairs hypothalamic glucose sensing but not glucose hypothalamic extracellular levels, as measured by microdialysis. Nutrition and Diabetes 5 1-8. (doi:10.1038/nutd.2015.12)

De Boer SF \& Van der Gugten J 1987 Daily variations in plasma noradrenaline, adrenaline and corticosterone concentrations in rats. Physiology and Behavior 40 323-328. (doi:10.1016/00319384(87)90054-0)

de Gortari P \& Mengod G 2010 Dopamine D1, D2 and mu-opioid receptors are co-expressed with adenylyl cyclase 5 and phosphodiesterase 7B mRNAs in striatal rat cells. Brain Research 1310 37-45. (doi:10.1016/j.brainres.2009.11.009)

Elias CF, Aschkenasi C, Lee C, Kelly J, Ahima RS, Bjorbaek C, Flier JS, Saper CB \& Elmquist JK 1999 Leptin differentially regulates NPY and POMC neurons projecting to the lateral hypothalamic area. Neuron 23 775-786. (doi:10.1016/S0896-6273(01)80035-0)

Epel ES 2009 Psychological and metabolic stress: a recipe for accelerated cellular aging? Hormones 8 7-22. (doi:10.14310/horm.2002.1217)

Fekete C, Sarkar S, Rand WM, Harney JW, Emerson CH, Bianco AC Beck-Sickinger A \& Lechan RM 2002 Neuropeptide Y1 and Y5 receptors mediate the effects of neuropeptide Y on the hypothalamicpituitary-thyroid axis. Endocrinology 143 4513-4519. (doi:10.1210/ en.2002-220574)

Fekete C, Singru PS, Sanchez E, Sarkar S, Christoffolete MA, Riberio RS, Rand WM, Emerson CH, Bianco AC \& Lechan RM 2006 Differential effects of central leptin, insulin, or glucose administration during fasting on the hypothalamic-pituitary-thyroid axis and feeding-related neurons in the arcuate nucleus. Endocrinology 147 520-529. (doi:10.1210/en.2005-0956)

Flegal KM, Kruszon-Moran D, Carroll MD, Fryar CD \& Ogden CL 2016 Trends in obesity among adults in the United States, 2005 to 2014. JAMA 315 2284-2291. (doi:10.1001/jama.2016.6458)

Franco JG, Fernandes TP, Rocha CP, Calvino C, Pazos-Moura CC, Lisboa PC, Moura EG \& Trevenzoli IH 2012 Maternal high-fat diet induces obesity and adrenal and thyroid dysfunction in male rat offspring at weaning. Journal of Physiology $\mathbf{5 9 0} 5503-5518$. (doi:10.1113/jphysiol.2012.240655)

Geer EB, Shen W, Gallagher D, Punyanitya M, Looker HC, Post KD \& Freda PU 2010 MRI assessment of lean and adipose tissue distribution in female patients with Cushing's disease. Clinical Endocrinology 73 469-475. (doi:10.1111/j.1365-2265.2010.03829.x)

Gill S \& Panda S 2015 A smartphone app reveals erratic diurnal eating patterns in humans that can be modulated for health benefits. Cell Metabolism 22 789-798. (doi:10.1016/j.cmet.2015.09.005)

Hatori M, Vollmers C, Zarrinpar A, DiTacchio L, Bushong EA, Gill S, Leblanc M, Chaix A, Joens M, Fitzpatrick JA, et al. 2012 Time-restricted feeding without reducing caloric intake prevents metabolic diseases in mice fed a high-fat diet. Cell Metabolism $\mathbf{1 5}$ 848-860. (doi:10.1016/j.cmet.2012.04.019) 
Honma KI, Honma S \& Hiroshige T 1983 Critical role of food amount for prefeeding corticosterone peak in rats. American Journal of Physiology 245 R339-R344.

Imai E, Stromstedt PE, Quinn PG, Carlstedt-Duke J, Gustafsson JA \& Granner DK 1990 Characterization of a complex glucocorticoid response unit in the phosphoenolpyruvate carboxykinase gene. Molecular and Cellular Biology 10 4712-4719. (doi:10.1128/ MCB.10.9.4712)

Jordan D, Rousset B, Perrin F, Fournier M \& Orgiazzi J 1980 Evidence for circadian variations in serum thyrotropin, 3,5,3'-triiodothyronine and thyroxine in the rat. Endocrinology 107 1245-1248. (doi:10.1210/ endo-107-4-1245)

Kakucska I, Qi Y \& Lechan RM 1995 Changes in adrenal status affect hypothalamic thyrotropin-releasing hormone gene expression in parallel with corticotropin-releasing hormone. Endocrinology 136 2795-2802. (doi:10.1210/en.136.7.2795)

Kalra SP, Dube MG, Sahu A, Phelps CP \& Kalra PS 1991 Neuropeptide Y secretion increases in the paraventricular nucleus in association with increased appetite for food. PNAS 88 10931-10935. (doi:10.1073/ pnas.88.23.10931)

Konno J, Yoshida S, Ina A, Ohmomo H, Shutoh F, Nogami H \& Hisano S 2008 Upregulated expression of neuropeptide Y in hypothalamic-pituitary system of rats by chronic dexamethasone administration. Neuroscience Research 60 259-265. (doi:10.1016/j. neures.2007.11.005)

Kow LM and Pfaff DW 1991 The effects of the TRH metabolite cyclo(His-Pro) and its analogs on feeding. Pharmacology, Biochemistry and Behavior 38 359-364. (doi:10.1016/0091-3057(91)90291-9)

La Fleur SE, Akana SF, Manalo SL \& Dallman MF 2004 Interaction between corticosterone and insulin in obesity: regulation of lard intake and fat stores. Endocrinology 145 2174-2185. (doi:10.1210/ en.2003-1359)

La Fleur SE, Kalsbeek A, Wortel J \& Buijs RM 1999 A suprachiasmatic nucleus generated rhythm in basal glucose concentrations. Journal of Neuroendocrinology 11 643-652. (doi:10.1046/j.13652826.1999.00373.x

Lamia KA, Sachdeva UM, DiTacchio L, Williams EC, Alvarez JG, Egan DF, Vasquez DS, Juguilon H, Panda S, Shaw RJ, et al. 2009 AMPK regulates the circadian clock by cryptochrome phosphorylation and degradation. Science 326 437-440. (doi:10.1126/science.1172156)

Lanni A, Moreno M, Lombardi A \& Goglia F 2003 Thyroid hormone and uncoupling proteins. FEBS Letters 543 5-10. (doi:10.1016/S00145793(03)00320-X)

Lee GC, Yang IM, Kim BJ, Woo JT, Kim SW, Kim JW, Kim YS \& Choi YK 1996 Identification of glucocorticoid response element of the rat TRH gene. Korean Journal of Internal Medicine 11 138-144. (doi:10.3904/ kjim.1996.11.2.138)

Legradi G, Emerson CH, Ahima RS, Flier JS \& Lechan RM 1997 Leptin prevents fasting-induced suppression of prothyrotropin-releasing hormone messenger ribonucleic acid in neurons of the hypothalamic paraventricular nucleus. Endocrinology 138 2569-2576. (doi:10.3904/ kjim.1996.11.2.138)

Legradi G \& Lechan RM 1998 The arcuate nucleus is the major source for neuropeptide Y-innervation of thyrotropin-releasing hormone neurons in the hypothalamic paraventricular nucleus. Endocrinology 139 3262-3270. (doi:10.1210/en.139.7.3262)

Lin B, Morris DW \& Chou JY 1998 Hepatocyte nuclear factor 1alpha is an accessory factor required for activation of glucose-6-phosphatase gene transcription by glucocorticoids. DNA and Cell Biology 17 967-974. (doi:10.1089/dna.1998.17.967)

Lopez M, Lage R, Saha AK, Perez-Tilve D, Vazquez MJ, Varela L, Sangiao-Alvarellos S, Tovar S, Raghay K, Rodriguez-Cuenca S, et al. 2008 Hypothalamic fatty acid metabolism mediates the orexigenic action of ghrelin. Cell Metabolism 7 389-399. (doi:10.1016/ j.cmet.2008.03.006)
Marin P, Darin N, Amemiya T, Andersson B, Jern S \& Bjorntorp P 1992 Cortisol secretion in relation to body fat distribution in obese premenopausal women. Metabolism 41 882-886. (doi:10.1016/00260495(92)90171-6)

Marks JL, Li M, Schwartz M, Porte D Jr \& Baskin DG 1992 Effect of fasting on regional levels of neuropeptide $\mathrm{Y}$ mRNA and insulin receptors in the rat hypothalamus: An autoradiographic study. Molecular and Cellular Neuroscience 3 199-205. (doi:10.1016/1044-7431(92)90039-5)

Mistry AM, Swick A \& Romsos DR 1999 Leptin alters metabolic rates before acquisition of its anorectic effect in developing neonatal mice. American Journal of Physiology 277 R742-R747.

Mitchell SE, Nogueiras R, Morris A, Tovar S, Grant C, Cruickshank M, Rayner DV, Dieguez C \& Williams LM 2009 Leptin receptor gene expression and number in the brain are regulated by leptin level and nutritional status. Journal of Physiology 587 3573-3585. (doi:10.1113/ jphysiol.2009.173328)

Morley JE \& Levine AS 1980 Thyrotropin releasing hormone (TRH) suppresses stress induced eating. Life Sciences 27 269-274. (doi:10.1016/0024-3205(80)90147-2)

Mullur R, Liu YY \& Brent GA 2014 Thyroid hormone regulation of metabolism. Physiological Reviews 94 355-382. (doi:10.1152/ physrev.00030.2013)

Ogden CL, Carroll MD, Lawman HG, Fryar CD, Kruszon-Moran D, Kit BK \& Flegal KM 2016 Trends in obesity prevalence among children and adolescents in the United States, 1988-1994 through 2013-2014. JAMA 315 2292-2299. (doi:10.1001/jama.2016.6361)

Paxinos G \& Watson C 2005 The Rat Brain in Stereotaxic Coordinates, edn 5th. Burlington, MA, USA: Elsevier.

Perello M, Cakir I, Cyr NE, Romero A, Stuart RC, Chiappini F, Hollenberg AN \& Nillni EA 2010 Maintenance of the thyroid axis during diet-induced obesity in rodents is controlled at the central level. American Journal of Physiology: Endocrinology and Metabolism 299 E976-E989. (doi:10.1152/ajpendo.00448.2010)

Qin LQ, Li J, Wang Y, Wang J, Xu JY \& Kaneko T 2003 The effects of nocturnal life on endocrine circadian patterns in healthy adults. Life Sciences 73 2467-2475. (doi:10.1016/S0024-3205(03)00628-3)

Rebuffe-Scrive M, Walsh UA, McEwen B \& Rodin J 1992 Effect of chronic stress and exogenous glucocorticoids on regional fat distribution and metabolism. Physiology and Behavior 52 583-590. (doi:10.1016/00319384(92)90351-2)

Reinehr T 2010 Obesity and thyroid function. Molecular and Cellular Endocrinology 316 165-171. (doi:10.1016/j.mce.2009.06.005)

Rohner-Jeanrenaud F, Walker CD, Greco-Perotto R \& Jeanrenaud B 1989 Central corticotropin-releasing factor administration prevents the excessive body weight gain of genetically obese $(\mathrm{fa} / \mathrm{fa}$ ) rats. Endocrinology 124 733-739. (doi:10.1210/endo-124-2-733)

Ruiter M, La Fleur SE, Van HC, van der V, Kalsbeek A \& Buijs RM 2003 The daily rhythm in plasma glucagon concentrations in the rat is modulated by the biological clock and by feeding behavior. Diabetes 52 1709-1715. (doi:10.2337/diabetes.52.7.1709)

Salgado-Delgado R, Nadia S, Angeles-Castellanos M, Buijs RM \& Escobar C 2010 In a rat model of night work, activity during the normal resting phase produces desynchrony in the hypothalamus. Journal of Biological Rhythms 25 421-431. (doi:10.1177/0748730410383403)

Sarkar S, Legradi G \& Lechan RM 2002 Intracerebroventricular administration of alpha-melanocyte stimulating hormone increases phosphorylation of CREB in TRH- and CRH-producing neurons of the hypothalamic paraventricular nucleus. Brain Research 945 50-59. (doi:10.1016/S0006-8993(02)02619-7)

Savontaus E, Conwell IM \& Wardlaw SL 2002 Effects of adrenalectomy on AGRP, POMC, NPY and CART gene expression in the basal hypothalamus of fed and fasted rats. Brain Research 958 130-138. (doi:10.1016/S0006-8993(02)03674-0)

Schmoll D, Allan BB \& Burchell A 1996 Cloning and sequencing of the $5^{\prime}$ region of the human glucose-6-phosphatase gene: transcriptional 
regulation by cAMP, insulin and glucocorticoids in H4IIE hepatoma cells. FEBS Letters 383 63-66. (doi:10.1016/0014-5793(96)00224-4)

Shimizu H, Arima H, Watanabe M, Goto M, Banno R, Sato I, Ozaki N, Nagasaki H \& Oiso Y 2008 Glucocorticoids increase neuropeptide $\mathrm{Y}$ and agouti-related peptide gene expression via adenosine monophosphate-activated protein kinase signaling in the arcuate nucleus of rats. Endocrinology 149 4544-4553. (doi:10.1210/ en.2008-0229)

Tsai JY, Villegas-Montoya C, Boland BB, Blasier Z, Egbejimi O, Gonzalez R, Kueht M, McElfresh TA, Brewer RA, Chandler MP, et al. 2013 Influence of dark phase restricted high fat feeding on myocardial adaptation in mice. Journal of Molecular and Cellular Cardiology 55 147-155. (doi:10.1016/j.yjmcc.2012.09.010)
Wittmann G, Fuzesi T, Singru PS, Liposits Z, Lechan RM \& Fekete C 2009 Efferent projections of thyrotropin-releasing hormone-synthesizing neurons residing in the anterior parvocellular subdivision of the hypothalamic paraventricular nucleus. Journal of Comparative Neurology 515 313-330. (doi:10.1002/cne.22017)

Zakrzewska KE, Cusin I, Sainsbury A, Rohner-Jeanrenaud F \& Jeanrenaud B 1997 Glucocorticoids as counterregulatory hormones of leptin: toward an understanding of leptin resistance. Diabetes $\mathbf{4 6}$ 717-719. (doi:10.2337/diab.46.4.717)

Zilberfarb V, Siquier K, Strosberg AD \& Issad T 2001 Effect of dexamethasone on adipocyte differentiation markers and tumour necrosis factor-alpha expression in human PAZ6 cells. Diabetologia 44 377-386. (doi:10.1007/s001250051630)

Received in final form 23 September 2016 Accepted 11 October 2016

Accepted Preprint published online 11 October 2016
๑) 2017 Society for Endocrinology Printed in Great Britain
Published by Bioscientifica Ltd 